\section{Análise virológica do carcinoma hepatocelular "não-B, não-C" e o envolvimento freqüente do vírus da hepatite $B$}

\author{
Francisco R. Santos \\ Hospital Bom Jesus - Ariquemes - Rondônia
}

\section{Sr. Editor,}

Apresento neste relato uma análise do estudo de Yotsuyanagi e colaboradores, sobre o envolvimento do vírus da hepatite $\mathrm{B}$ e outros vírus na etiologia do carcinoma hepatocelular não B não $\mathrm{C}$.

Os autores pesquisaram a presença de ácido nucleico de três vírus, o vírus da Hepatite B (HBV), da hepatite C (HCV), e do Transfusion Transmitted Virus (TTV) em pacientes acometidos de carcinoma hepatocelular (CHC) no Japão.

Estes pacientes são negativos para o antígeno $\mathrm{HBs}$ (AgHBs) e anticorpos (ACS) anti- HCV. Lembram que no Japão $5 \%$ dos pacientes são portadores de CHC sem AgHBs e sem anticorpos anti-HCV. Estes CHC são qualificados de "não-B, não-C": A prevalência das infecções HBV e HCV na população japonesa é aproximadamente $1 \%$.

Nos 42 paciente acometidos ( 35 homens e 7 mulheres), onde 5 têm antecedentes transfusionais, os 3 vírus citados foram pesquisados por biologia molecular no soro e no tecido hepático. Um grupo de 42 pessoas, sem doença hepática, com idades similares, foi recrutado e testado. Uma PCR de sensibilidade de 10 cópias por ensaio foi utilizada para pesquisa do DNA do HBV, enquanto uma RT- PCR permitia a evidencia de RNA deste vírus. Enfim, um sequenciamento e uma semiquantificação do DNA do HBV foram efetuados nos pacientes.

Os 42 pacientes foram divididos em 3 grupos do ponto de vista dos marcadores do HBV. Vinte e seis (26) pacientes foram negativos para anti-HBs e anti-HBc (Grupo 1), 9 apresentaram somente anti-HBc (Grupo 2) e 7 foram positivos para os 2 tipos de marcadores (Grupo 3). Nas 42 pessoas do grupo controle, 32 foram negativos para as 2 categorias de anticorpos, 6 positivos somente para anti-HBc e 4 positivos para os dois marcadores. Um total de 20 pacientes dentre 42 testados apresentaram DNA do HBV no soro, ou seja, 47,6\% contra somente 1 para os controles $(2,4 \%)$, resultando que foi estatisticamente significativo.

A taxa mais elevada $(53,8 \%, 14$ casos em 26$)$ ocorreu no Grupo 1. Na análise do tecido hepático de 12 destes pacientes, os autores encontraram o DNA do HBV em 8 deles $(66,7 \%)$ no local do envolvimento neoplásico. A análise semiquantitativa do DNA do HBV revelou a presença de ao menos uma cópia por célula neoplásica contra menos de uma nas células normais (a presença de DNA do HBV nesta categoria de células é ocasional). A transcrição do genoma do HBV foi detectada devido à existência de RNA do HBV no tecido hepático de todos pacientes, seja no tecido neoplásico ou não, salvo por uma paciente no tecido canceroso unicamente. Em certos pacientes o sequenciamento do DNA do HV mostrou mutações e/ou deleções que podem explicar a ausência de marcadores do HBV em certos casos.
Em nenhum paciente o RNA do HCV foi detectado. Para o TTV, a prevalência do DNA foi de $83,8 \%$ no soro de 42 pacientes (35 casos), contra 95,2\% nas pessoas controles ( 40 casos em 42). No fígado, 8 pacientes em 12 são portadores de DNA do TTV.

Este estudo mostra que no Japão, a implicação do HBV nos pacientes portadores de $\mathrm{CHC}$ qualificados de "não-B, nãoC", é freqüente. A presença de mutações e/ou deleções no genoma HBV de certos pacientes poderá explicar a ausência de marcadores deste vírus, notadamente o AgHBs circulante. Estas constatações feitas na população de doentes podem, entretanto, ser relacionadas à problemática de falsos negativos observados em certos testes de detecção de AgHBs (ausência de AgHBs circulante, não-produção de AgHBs, AgHBs mutante não detectado...) em doadores de sangue.

A biologia molecular neste estudo confirma e permite revelar a presença de uma infecção com o HBV nos pacientes portadores de CHC sem marcadores sorológicos detectáveis do HBV.

No futuro, ela poderá provavelmente evidenciar infecções HBV nos doadores de sangue negativos pelos testes de triagem de AgHBs, anticorpos anti-HBc e anti-HBs. A biologia molecular cada vez mais assumirá um papel complementar à sorologia no domínio clínico e na segurança transfusional. Também permitirá estudar o aparecimento de mutações e de seguir sua evolução em diferentes populações devendo o mesmo ser estendido também a populações brasileiras.

Virus analysis of hepatocellular carcinoma "non-A, non- $C$ " and hepatitis $B$ virus

Francisco R. Santos

\section{Abstract}

This paper is an analysis of the study by Yotsuyanagi et al. about the association of hepatitis $B$ and other viruses in the etiology of non- $B$ and non-C hepatocellular carcinomas.

The authors tested for hepatitis $B$, hepatitis $C$ and transfusion transmitted virus in patients suffering from hepatocellular carcinomas in Japan.

Although many of these patients were negative in respect to anti-HBs and/or anti-HBc, using PCR it was possible to prove many individuals exhibited DNA of hepatitis B virus in the blood serum. The most significantly findings were in patients negative for both anti-HBs and anti-HBc. Using RT-PCR the presence of RNA of hepatitis B virus was found in the hepatic tissue in all cases, whether neoplastic or not, except in one patient.

\section{Referências Bibliográficas}

- Yotsuyanagi H. et al. Análise virológica da carcinoma bepatocelular " não- B não- $C$ ” no Japão: envolvimento freqüente do vírus da hepatite $B$. The Journal of Infectious Diseases. 2000. 181:1920-1928.

Recebido: 19/02/01

Aceito: 10/03/01

Correspondência: Francisco R. Santos

Av. dos Migrantes, 200. Setor Hospitalar. CEP: 78.932-000

Ariquemes. Rondônia

Fone: (69) 224-7752. Cel. (69) 9981-9113 